\title{
Schumpeter, utylitaryzm i teoria demokracji
}

\section{Schumpeter, Utilitarianism and Democratic Theory}

\begin{abstract}
Joseph Schumpeter's theory of democracy as a method of selection of political elites remains one of the most influential, as well as most controversial reference points in contemporary debates concerning democracy. The article argues, however, that Schumpeter tries to create a misleading opposition between his own theory and the classical theory of democracy, the latter of which apparently espoused by utilitarians like Jeremy Bentham and James Mill. Firstly, most of the Schumpeter's objections to the utilitarian account of democracy miss the mark. Secondly, there are similarities and lines of continuity between the theory of democracy which was espoused by classical utilitarianism and Schumpeter's own theory. For instance, in classical utilitarianism one can find an evident elitist component which was later further emphasized by Schumpeter as a result of him modelling his account of democratic politics on the (oligopolic) market competition.
\end{abstract}

Keywords: democracy, elitism, Joseph A. Schumpeter, utilitarianism

Od czasu ukazania się pierwszego wydania książki Josepha Schumpetera Kapitalizm, socjalizm, demokracja upłynęło ponad 75 lat. Praca ta wzbudziła duże zainteresowanie, co ciekawe, na początku głównie wśród politologów i socjologów, a nie ekonomistów, do których grona zaliczał się sam autor (Held, 2006, s. 141). Przedstawione w niej ujęcie demokracji wpłynęło na wielu znaczących badaczy demokracji (Dahl, 1961; Przeworski, 1999; Sartori, 1998). Być może silniejsze nawet okazało się jej negatywne oddziaływanie, nie brakuje bowiem autorów i dzieł zdecydowanie krytycznych wobec Schumpeterowskiej teorii demokracji. Dość wymowne jest zresztą to, że nawet ci, którzy odnieśli się do tej ostatniej z sympatią, w swoich własnych pracach starali się złagodzić niektóre z tez austriackiego uczonego.

Tematem niniejszego artykułu nie jest jednakże recepcja teorii demokracji Schumpetera. Skupiam się w nim na pewnym wątku zawartym w jej oryginalnym sformułowaniu. Zagadnienie to ma charakter historyczny, choć nie jest też zupełnie pozbawione związków ze współczesnością. Otóż autor pracy Kapita- 
lizm, socjalizm, demokracja przeciwstawia własne, rzekomo realistyczne ujęcie demokracji - klasycznej teorii rządów ludu ${ }^{1}$. Co ciekawe, Schumpeter jako eksponentów tej ostatniej, a więc jednocześnie jako obiekt swoich polemicznych ataków, wskazuje reprezentantów klasycznego utylitaryzmu. Chciałbym wykazać, że przeprowadzona przez Schumpetera krytyka teorii demokracji głoszonej przez utylitarystów jest zwodnicza. Co za tym idzie, w błąd wprowadzać może również dokonana przezeń prezentacja własnego stanowiska. Zapoznaje ona bowiem podobieństwa i ciągłości pomiędzy charakterystyczną dla klasycznego utylitaryzmu teorią demokracji a pretendującą do znacznie większego realizmu teorią samego Schumpetera.

Aby zrealizować tak wytyczony cel, artykuł podzielony został na kilka części. W pierwszej kolejności zajmę się nakreśleniem głównych zarzutów Schumpetera pod adresem klasycznej teorii demokracji oraz kluczowych założeń jego własnej teorii. Następnie przejdę do omówienia argumentacji na rzecz demokracji zawartej w Eseju o rządzie Jamesa Milla, który uchodzi za „kanoniczny” wykład stanowiska klasycznych utylitarystów, zwanych na początku XIX wieku także „filozoficznymi radykałami”. Wówczas możliwe stanie się porównanie ze sobą obu teorii i zidentyfikowanie podobieństw, których sam Schumpeter zdaje się nie dostrzegać.

Krótkiego wyjaśnienia domaga się także motywacja powstania niniejszego artykułu. Omawiane w nim zagadnienie w mojej opinii samo w sobie powinno budzić zainteresowanie historyka myśli politycznej, w szczególności jeśli jego badania dotyczą teorii demokracji. Jeśli jednak nie jest to wystarczający powód, możliwe jest wskazanie także innego. Trudno zaprzeczyć, że lektura Schumpetera pozwala trafnie zidentyfikować przynajmniej niektóre ograniczenia i słabości klasycznej teorii demokracji². Jeśli jednak błędnie interpretuje on niektóre różnice dzielące jego własne ujęcie demokracji od stanowiska klasycznych utylitarystów w tej kwestii, to analiza tego ostatniego pozwala krytycznie spojrzeć też na teorię austriackiego uczonego. Rzuca to pewne światło również na koncep-

Schumpeter preferuje posługiwanie się określeniem „klasyczna doktryna demokracji”. Ponieważ jednak sam nie jest konsekwentny w tym wyborze i miejscami wykorzystuje w tym kontekście także pojęcie „teoria”, w niniejszym tekście będę stosował frazę „klasyczna teoria demokracji".

2 W przeciwieństwie do Schumpetera nie uważam, że mówić należy tylko o jednej klasycznej teorii demokracji. Za twórcę alternatywnej wobec utylitarystycznej teorii demokracji może przecież uchodzić chociażby Jean-Jacques Rousseau. Co ciekawe jednak, nazwisko tego ostatniego zostaje przez Schumpetera wymienione w części IV pracy Kapitalizm, socjalizm, demokracja bodaj tylko raz. Jest to tym bardziej zaskakujące, że niektóre z zarzutów, jakie Schumpeter stawia klasycznej teorii demokracji, w większym stopniu pasowałyby właśnie do Rousseau niż klasycznych utylitarystów. Aby jednak nie wprowadzać konfuzji, w niniejszym tekście podążę za Schumpeterem i stosował będę określenie „klasyczna teoria demokracji”. 
cje bardziej nam współczesnych kontynuatorów dzieła Schumpetera, nawet jeśli nie zawsze wprost zdradzają oni swoje intelektualne długi wobec autora Kapitalizmu, socjalizmu, demokracji.

\section{Rządy ludu lub selekcja elit}

Schumpeter chce czasem sprawiać wrażenie, często z powodzeniem, jeśli wziąć pod uwagę opinie wielu jego interpretatorów (Medearis, 2001, s. 142-144), że prezentuje bezstronne, pozbawione wartościowania ujęcie demokracji. Opierając się na empirycznych danych, oddzielając fakty od wartości, orzekać ma sine ira et studio o tym, co rządy ludu oznaczają w praktyce, jaką formę przybierają i muszą przybierać. Schumpeterowską krytykę klasycznej teorii demokracji oraz zaproponowane przezeń alternatywne ujęcie demokracji trudno jest wszakże w pełni zrozumieć bez usytuowania ich w historycznym i poniekąd również biograficznym kontekście ich powstania. John Medearis wskazuje na pokrewieństwo między refleksją Schumpetera a pewnym specyficznym kręgiem krytyków demokracji. Do grona tego zaliczają się postaci takie jak: de Tocqueville, Weber, Pareto, Mosca, Le Bon, Michels (Medearis, 2001, s. 4-5). Zdradzali oni konserwatywną nieufność wobec skutków postępującej demokratyzacji, ale jednocześnie uważali zwycięstwo demokracji za nieuniknione. Celem, jaki sobie wobec tego stawiali, było przedstawienie takich rozwiązań, które pozwoliłyby na poskromienie niebezpiecznego demokratycznego żywiołu, skanalizowanie jego siły w taki sposób, aby ocalić wartości, którym miałby on zagrażać, lub przynajmniej zminimalizować wyrządzane przezeń szkody. W tym sensie rzeczywiście można mówić o jawnej i ukrytej obecności w myśli Schumpetera pewnej transformacyjnej koncepcji demokracji, która stanowić ma kontrapunkt dla jego własnej, głęboko konserwatywnej i elitarystycznej teorii demokracji. W czasach Schumpetera taka transformacyjna koncepcja znalazła swój wyraz w dążeniach do zaprowadzenia już nie tyle demokracji politycznej, ile społecznej, a więc zastąpienia kapitalizmu przez jakąś formę socjalizmu. Biograficzne uwikłanie Schumpetera w polityczne konflikty powstałe po rozpadzie monarchii habsburskiej, a następnie poczynione przezeń obserwacje dotyczące amerykańskiego eksperymentu z programem New Deal wydają się potwierdzać taką interpretację (Medearis, 2001, s. 19-95). To, co austriacki uczony uznał za klasyczną teorię demokracji, stanowi zatem część pewnego ważnego wątku jego myśli związanego z przemianami społecznymi i politycznymi, których się obawiał.

Autor Kapitalizmu, socjalizmu, demokracji obiera sobie za główny przedmiot ataku dwa założenia tego, co uznaje za klasyczną teorię demokracji. Po pierwsze, teoria ta zakładać ma jego zdaniem, iż istnieje pewne wspólne dobro, 
„[...] oczywisty punkt orientacyjny polityki, który zawsze bez trudu można zdefiniować i który zawsze może być rozpoznany przez każdą normalną jednostkę przy zastosowaniu racjonalnej argumentacji” (Schumpeter, 2009, s. 312). Obywatele działający jako racjonalne jednostki otwarte na dialog i argumentację są w stanie osiągnąć dobrowolne porozumienie co do tego wspólnego dobra, a następnie zastosować odpowiednie polityczne środki zmierzające do jego praktycznej realizacji. Według Schumpetera jest to oczywiście obraz bardzo naiwny, opierający się na złudzeniach dogmatycznego, oświeceniowego racjonalizmu, które już dawno temu powinny zostać zarzucone. Zamiast jednolitego, wspólnego dobra, które odkryć można byłoby drogą racjonalnej argumentacji, austriacki uczony zdaje się afirmować stanowisko bliskie pluralizmowi wartości. W passusie przywodzącym na myśl powstałe nieco później dzieła sir Isaiaha Berlina stwierdza on, iż: „[...] dla różnych jednostek i grup dobro wspólne mu si [podkr. K.A.] mieć różne znaczenie. Fakt ten, którego nie dostrzega wąskie, utylitarystyczne spojrzenie na świat, będzie powodował rozbieżności co do zasadniczych kwestii [...]; ostateczne wartości - nasze pojmowanie pożądanego kształtu życia i społeczeństwa - wykraczają poza ramy wyznaczone samą logiką. Rozbieżności te można usunąć $\mathrm{w}$ niektórych przypadkach w drodze kompromisu, w innych jednak okazuje się to niemożliwe" (Schumpeter, 2009, s. 314).

Negacja przez Schumpetera koncepcji wspólnego dobra odwołujących się do racjonalistycznego monizmu stanowi jednocześnie cios wymierzony w drugi z filarów klasycznej teorii demokracji - w ideę woli ludu. Schumpeter zgłasza pod jej adresem kilka zastrzeżeń. Wydaje się jednak, że kluczowe znaczenie dla jego argumentacji ma twierdzenie o zasadniczej nieracjonalności woli i osądu zwykłych obywateli w politycznych kwestiach. Wykorzystywany przez klasyczną ekonomię model człowieka jako homo economicus, skrupulatnie i racjonalnie kalkulującego koszty i korzyści płynące dlań z każdego działania, tylko częściowo przystaje do zachowań obserwowanych w rzeczywistości. O ile Schumpeter jest skłonny przyznać, że w wielu sprawach codziennego życia zwykli ludzie dysponują wystarczająco określoną wolą i potrafią działać zgodnie z wymogami racjonalności instrumentalnej, o tyle zdaniem austriackiego ekonomisty trudno w podobny sposób opisać działania polityczne zwykłych obywateli. Kwestie polityczne są bowiem zbyt odległe od ich zwykłych zajęć, a przez to zbyt abstrakcyjne i pozbawione korygującego wpływu doświadczenia, aby potrafili je oni kompetentnie ocenić. Schumpeter w duchu takich teoretyków psychologii tłumu jak Gustave Le Bon utrzymuje, iż: „[...] typowy obywatel, skoro tylko wkracza w sferę polityki, spada na niższy poziom sprawności umysłowej. Argumentuje on i analizuje w sposób, który w zastosowaniu do sfery swoich realnych interesów sam bez trudu uznałby za infantylny. Staje się na powrót prymitywem [podkr. K.A.]. Jego myślenie nabiera cech emocjonalnych i asocja- 
cyjnych" (Schumpeter, 2009, s. 327). Dodać do tego należy różne socjotechniki wykorzystywane przez partie polityczne, grupy interesów gospodarczych, media, wpływ tego, co w czasach Schumpetera zwano propagandą, a współcześnie często nosi miano marketingu politycznego i PR-u. W rezultacie Schumpeter dochodzi do wniosku, że hołubiona przez klasyczną teorię demokracji volonté generale jest fantomem. Preferencje ujawniane w polityce przez obywateli nie mogą być traktowane jako ekspresja ich autonomicznej woli. Stanowią one bowiem wyraz woli odpowiednio uprzednio ukształtowanej przez zainteresowanych tym aktorów, „woli sfabrykowanej”. Schumpeter wprost twierdzi, że: „Sposób, w jaki produkowane [podkr. K.A.] są problemy i wola ludu w odniesieniu do poszczególnych problemów, jest dokładnym odpowiednikiem reklamy handlowej" (Schumpeter, 2009, s. 328).

W związku z tym Schumpeter proponuje odmienną, jego zdaniem zdecydowanie bardziej realistyczną, teorię demokracji. Demokracja stanowi tutaj instytucjonalne rozwiązanie, które bynajmniej nie realizuje woli ludu, a zapewnia skuteczną i pokojową selekcję politycznych przywódców. Demokratyczność takiego ustroju ma polegać na tym, że aspirujących do przywództwa jest wielu i że rywalizują oni ze sobą o akceptację wyborców. Demos nie sprawuje rządów, cała realna władza spoczywa bowiem w rękach politycznych elit, lud natomiast pozostaje niemal zupełnie pasywny. Jego rola ogranicza się do zaakceptowania bądź odrzucenia rządów konkretnej grupy polityków. Dlatego też Schumpeter świadomie unika odwołania się w swojej definicji demokracji do pojęcia woli powszechnej, uznając, iż: „[...] metoda demokratyczna jest tym rozwiązaniem instytucjonalnym dochodzenia do decyzji politycznych, w którym jednostki uzyskują moc decydowania poprzez walkę konkurencyjną o głosy wyborców" (Schumpeter, 2009, s. 336-337).

\section{James Mill o demokracji}

Czy jednak zarzuty Schumpetera pod adresem klasycznej teorii demokracji rzeczywiście znajdują potwierdzenie w przypadku klasycznych utylitarystów? W celu syntetycznego przedstawienia ich politycznych idei wybrałem Esej o rządzie autorstwa Jamesa Milla, który opublikowany został jako hasło w Encyclopaedia Britannica z 1820 roku. Dlaczego akurat ten tekst? Jest prawdą, że utylitarystyczna teoria demokracji w wersji Jamesa Milla odbiega pod pewnymi względami od stanowiska, jakie zajmował wobec rządów ludu Jeremy Bentham, główny twórca klasycznego utylitaryzmu. Z pewnością różni się ona również od ujęcia demokracji, jakie w swoich dojrzałych pismach zaproponował syn Jamesa Milla - John Stuart. Poglądy młodszego z Millów pozwolę sobie jednak w niniejszym tekście pominąć, jako że przedmiotem kontrowersji jest to, w jakim stopniu, o ile w ogóle, 
mieszczą się one w granicach utylitarystycznej ortodoksji. Tekst autorstwa Jamesa Milla uznaję zaś za reprezentatywne przedstawienie utylitarystycznej teorii demokracji, nawet po uwzględnieniu pewnych specyficznych cech jego argumentacji. Na rzecz takiej decyzji przemawia chociażby to, że pokolenie filozoficznych radykałów, do którego należał Mill senior, uznało Esej o rządzie za podręcznikową wręcz ekspozycję swojego politycznego credo. Należy jednak również zaznaczyć, że forma traktatu teoretycznego, jaką autor nadał temu tekstowi, bywa niekiedy zwodnicza. W czasie kiedy powstawał Esej o rzadzie, w Wielkiej Brytanii toczyły się gorące spory dotyczące ewentualnej reformy prawa wyborczego do parlamentu, dlatego też James Mill z praktycznych i jednocześnie politycznych względów nie zawsze zdradzał swoje prawdziwe poglądy. W tekście jego autorstwa pojawiają się więc zamierzone ekwiwokacje, niejasne sformułowania, niektórym argumentom brakuje konkluzji etc. (Hamburger, 1962, s. 169-171).

Mill opiera swoją argumentację na założeniu powszechnego egoizmu. Każda jednostka dąży do maksymalizacji własnej przyjemności (względnie minimalizacji cierpienia). Co więcej, zasoby niezbędne do zaspokojenia ludzkich potrzeb są ograniczone, a praca związana $\mathrm{z}$ ich przetwarzaniem wiąże się z przykrością. $Z$ tych dwóch przesłanek wynika, że w razie braku kontroli każdy człowiek starałby się zdobyć władzę nad innymi i uczynić z nich narzędzie maksymalizowania swojej przyjemności. Ten ponury, mocno Hobbesowski obraz wzajemnej rywalizacji napędzanej przez niemożliwe do zaspokojenia pragnienie władzy wyjaśnia jednocześnie powstanie państwa i jego instytucji. Ma ono bowiem zapewnić bezpieczeństwo osobiste oraz ochronę własności prywatnej. Problem w tym, że obdarzeni władzą sami niechybnie wykorzystają ją do realizacji partykularnych interesów, jeśli nie pojawi się jakiś hamulec, który ich przed tym powstrzyma. Chodzi zatem o to, aby sprawujący władzę także byli włączeni w strukturę polityczną tak skonstruowaną, by działając we własnym interesie, przyczyniali się jednocześnie do realizacji dobra ogólnego (Harrison, 1993, s. 94). Zdaniem Jamesa Milla jedynie demokracja reprezentatywna jest w stanie osiągnąć ten cel. Gdyby bowiem prawo wybierania rządzących przysługiwało tylko jakiejś części społeczeństwa, powiedzmy najbogatszym lub szlachetnie urodzonym, władza miałaby na względzie tylko interesy tej grupy. Jak powiada Mill: „korzyści systemu przedstawicielskiego są stracone we wszystkich przypadkach, w których interesy ciała wyborczego nie są identyczne z interesami społeczności" (Mill, 2001, s. 243). Należy podkreślić, że logika argumentacji Milla jednoznacznie uzasadnia wprowadzenie powszechnego prawa wyborczego, choć on sam cofa się przed taką konkluzją (Mill, 2001, s. 243)33. Inne założenie jego teorii demokracji głosi,

Więcej nawet, James Mill odmawia prawa głosu nie tylko kobietom, ale i mężczyznom przed 40. rokiem życia. 
że skoro większość reprezentantów wyłonionych w demokratycznych wyborach zamierza ubiegać się o reelekcję, w ich interesie leżeć będzie zadowolenie jak największej liczby wyborców. Jeśli dodatkowo kadencja organu reprezentatywnego byłaby krótka, nawet jednoroczna, czego orędownikiem był James Mill, parlamentarzyści w większym stopniu byliby politycznie odpowiedzialni przed społeczeństwem (Mill, 2001, s. 241).

\section{Dobro wspólne i wola ludu}

Taka krótka ekspozycja argumentów autora Eseju o rządzie na rzecz demokracji pozwoli teraz bardziej szczegółowo odnieść się do sposobu, w jaki Schumpeter odmalowuje klasyczną teorię demokracji.

Rozważmy najpierw kwestię dobra wspólnego. Klasyczny utylitaryzm nie ujmował tego ostatniego jako niezależnego od dóbr poszczególnych jednostek tworzących daną społeczność. Byłoby to niezgodne z nominalistyczną tradycją, w którą wpisywał się ten nurt. Jeremy Bentham, ojciec założyciel klasycznego utylitaryzmu, podkreślał, że: „Społeczeństwo jest rzekomym ciałem, złożonym $\mathrm{z}$ indywidualnych osób, które się traktuje, jakby stanowiły jego członki. Czymże jest wobec tego interes społeczeństwa? Sumą interesów składających się na nie jednostek" (Bentham, 1958, s. 149). Kiedy z kolei James Mill stwierdził w Eseju o rzadzie, że „Społeczność nie może mieć interesu w tym, co jest niezgodne z jej interesem" (Mill, 2013b, s. 266, przeł. K.A.), wypowiedział w gruncie rzeczy tę samą myśl. Interes społeczności każdorazowo i z definicji oznacza bowiem interes większości ludzi ją tworzących. Co więcej, utylitaryzm zrodził się jako teoria etyczna o wyraźnie indywidualistycznym rysie. Jego wyznawcy otaczali niemalże religijną czcią zasadę użyteczności zwaną inaczej zasadą największego szczęścia największej liczby ludzi. Celem indywidualnych i kolektywnych działań powinno być bezstronne maksymalizowanie szczęścia jednostek, a nie podmiotów zbiorowych w rodzaju klasy, narodu czy społeczeństwa ${ }^{4}$. Skoro sam Schumpeter dostrzega możliwość przedstawienia bardziej „realistycznej”, nie odwołującej się do społecznego holizmu koncepcji dobra wspólnego i woli ludu (Schumpeter, 2009, s. 315-316; Ingham, 2016, s. 1017), wypada zauważyć, że właśnie takową odnaleźć można w klasycznym utylitaryzmie.

\footnotetext{
Z tego, że każdy wchodzi do utylitarystycznej kalkulacji na identycznych zasadach, nie wynika jednak oczywiście, że konsekwencje zastosowania zasady użyteczności muszą być dla wszystkich jednostek korzystne. Krytycy utylitaryzmu niejednokrotnie podnosili zarzut, że utylitarystyczna moralność usprawiedliwia poświęcenie jednostek w imię dobra większości, na przykład zastosowanie tortur wobec niewinnej osoby, żeby zapobiec zamachowi terrorystycznemu etc.
} 
Schumpeter myli się, przypisując utylitarystom hiperracjonalistyczne wyobrażenie o dobru wspólnym i sposobie jego określenia. Jest prawdą, że ich zdaniem zasada użyteczności intuicyjnie przemawia do większości ludzi. Utylitarysta nie potrzebuje jednak (prawie) uniwersalnej zgody zadekretowanej werdyktem racjonalnej deliberacji, aby utwierdzić ją w roli najwyższego moralnego standardu. On po prostu wie, że takowym jest. Pytanie brzmi natomiast: czego w konkretnych okolicznościach wymaga realizacja zasady użyteczności? W tej kwestii utylitaryzm może bez problemu przystać na to, że jednostki i grupy podzielają pewne interesy. Klasyczni utylitaryści wierzyli, iż na przykład stabilność własności stanowi ponadklasowy interes (Harrison, 1993, s. 112). Utylitarystyczna teoria z pewnością przyzwala też na to, aby obywatele angażowali się $\mathrm{w}$ racjonalny dialog z innymi dotyczący wspólnych interesów. Musi ona jednak potraktować takie zaangażowanie również jako koszt związany z ubytkiem czasu i rezygnacją z innych możliwości działania. Żaden element utylitaryzmu nie gwarantuje ponadto, że racjonalna deliberacja poświęcona wspólnemu dobru doprowadzi do uzyskania pełnej zgody. Wspólne dobro nie wyłoni się także spontanicznie $\mathrm{z}$ indywidualnych dążeń jednostek, które poszukując własnej satysfakcji, okazują się w ostatecznej instancji pracować na korzyść innych. Jest prawdą, że w klasycznym utylitaryzmie odnaleźć można obraz człowieka jako istoty racjonalnie potrafiącej ocenić, na czym polega jej interes, i inteligentnie dobierać środki do jego zabezpieczenia. Przeprowadzona przez Schumpetera krytyka tego obrazu jako wąskiego, mechanistycznego i uproszczonego, choć w żadnym razie nie oryginalna, z pewnością nie jest pozbawiona podstaw. Jednocześnie jednak po raz kolejny wypada stwierdzić, że zanadto ułatwia on sobie sprawę. Klasyczni utylitaryści, właśnie z uwagi na to, że ich psychologia kładła nacisk na egoistyczne motywacje działań, dostrzegali konieczność zastosowania takich rozwiązań, które prowadzić będą do harmonizacji interesu indywidualnego i ogólnego. W szczególności dotyczy to ich teorii polityki, która zbudowana została na fundamencie nieufności wobec sprawujących władzę (Harrison, 1993, s. 96). Wspomniałem już chociażby o tym, że James Mill upatrywał w demokracji reprezentatywnej jedynej skutecznej metody na uzgodnienie dobra rządzących i rządzonych. Mówiąc bardziej ogólnie, teoria demokracji właściwa dla klasycznego utylitaryzmu zakładała stworzenie pewnej sztucznej harmonii interesów, a nie jej odkrycie jako już preegzystującej (Halévy, 1960, s. 13-18).

Schumpeterowska krytyka klasycznej teorii demokracji w pewnym sensie stoi natomiast na solidniejszym gruncie, gdy odnosi się do idei woli ludu. Filozoficzni radykałowie zakładali bowiem rzeczywiście, że demokratyczne wybory pozwalają zamanifestować się tej ostatniej. Jeśli każdy obywatel będzie głosować zgodnie ze swoim interesem, możemy uznać, że daje w ten sposób także wyraz swojej indywidualnej woli. Wynik wyborów stanowi zaś rezultat agregacji woli poszczególnych 
jednostek, a zatem wyłania się z nich coś, co można nazwać wolą ludu. Schumpeter zaprzecza jednak, jakoby obywatele przejawiali określoną i racjonalną wolę w decyzjach politycznych. Jeśli natomiast wydają się takową posiadać, to jest tak dlatego, że została ona uprzednio zmanipulowana przez polityczne elity. Wyborcy są więc wówczas rzeczywiście wyrazicielami określonych i racjonalnych dążeń, tyle że nie własnych. W tej kwestii teoria demokracji głoszona przez klasyczny utylitaryzm istotnie okazuje się nie do pogodzenia z twierdzeniami autora Kapitalizmu, socjalizmu, demokracji. Zdaniem Schumpetera demokracja bynajmniej nie oznacza, że: „[...] lud faktycznie rządzi, sprawuje władzę w jakimkolwiek oczywistym sensie przypisywanym określeniom »lud« i »rządzić«. Demokracja oznacza jedynie, że ludzie mają możliwość zaakceptowania lub odmowy zaakceptowania tych, którzy mają rządzić. [...] Jeden $\mathrm{z}$ aspektów sprawy można ująć $\mathrm{w}$ postaci powiedzenia, że demokracja oznacza rządy polityków" (Schumpeter, 2009, s. 355). Klasyczni utylitaryści uważali z kolei, że lud rzeczywiście może rządzić, choć w praktyce tylko za pomocą reprezentantów i jedynie w ograniczonym zakresie.

Problem z tym wątkiem Schumpeterowskiej krytyki polega jednakże na tym, iż niezbyt pochlebne opinie o politycznych kompetencjach zwykłych obywateli są przez austriackiego uczonego po prostu orzekane, bez silenia się na ich uzasadnianie. Być może obywatele w demokracji rzeczywiście są pasywni, nieświadomi, podatni na manipulację, ale Schumpeter nie przedstawia na to żadnych empirycznych dowodów. Nie oznacza to oczywiście, że takowe nie mogą zostać odnalezione. Ustalenia empirycznie zorientowanej politologii poczynione już po ukazaniu się Kapitalizmu, socjalizmu, demokracji pozwalają przynajmniej w pewnym zakresie wesprzeć generalizacje Schumpetera. Wątpliwe jest jednak, czy uzasadniają one równie mocne twierdzenia, jak te wysunięte pod adresem obywateli demokracji w tym dziele (Ingham, 2016, s. 1082-1083).

\section{Elitaryzm i ekonomia}

Podobnie jak w przypadku Schumpetera, warto na chwilę zatrzymać się nad kontekstem historycznym, w którym pojawiła się utylitarystyczna teoria demokracji. W XIX stuleciu rozpowszechnione były obawy związane ze znaczącym poszerzeniem prawa wyborczego. Arystokracja i znaczna część mieszczaństwa lękała się dopuszczenia do uczestnictwa w polityce niewykształconych i ubogich mas, w szczególności zaś tego, że owe masy dokonają wywłaszczenia dotychczasowych posiadaczy. Twierdzono, że pod wpływem prymitywnych instynktów i demagogicznej agitacji biedni nie będą w stanie zrozumieć, iż nie leży to w ich własnym interesie. Ale klasyczni utylitaryści nie żywili podobnych obaw. Z Schumpeterowskiego punktu widzenia, który zarysowałem, omawiając transformacyjną koncepcję 
demokracji obecną w jego myśli, autorzy tacy jak James Mill prezentują się jako naiwni radykałowie podsycający nierealistyczne i niebezpieczne dążenia do demokratyzacji. Chciałbym jednak zasugerować, że obraz ten pomija pewne elitarystyczne elementy od początku obecne w teorii demokracji forsowanej przez klasyczny utylitaryzm. Elementy te pozwalają także lepiej zrozumieć stoicki spokój, z jakim utylitaryści wyczekiwali na realizację swoich demokratycznych postulatów.

James Mill z optymizmem spoglądał w przyszłość $\mathrm{z}$ różnych względów. W sposób typowy dla klasycznego utylitaryzmu widział on receptę na potencjalne zagrożenia związane $\mathrm{z}$ poszerzeniem prawa wyborczego w edukacji niższych warstw społecznych. Mówiąc o edukacji, mam na myśli nie tyle formalne kształcenie, ile zdobywanie przez poszczególne jednostki adekwatnej wiedzy o tym, co leży w ich interesie. Wiedza tego rodzaju stanowi bowiem nieodzowny warunek racjonalnego wyboru, także w polityce. Ponieważ zaś Mill podobnie jak inni klasyczni utylitaryści był zwolennikiem asocjacjonistycznej psychologii, uważał, iż edukacja polega na stworzeniu dla edukowanego warunków do wzmacniania odpowiednich wrażeń i formowania nawyków myślowych. Polityczna edukacja byłaby więc w dużej mierze edukacją praktyczną, poprzez polityczną partycypację (Mill, 2013a, s. 216). W tym kontekście należy jednak podkreślić, że Mill liczył również na to, iż proces demokratyzacji da się kontrolować za sprawą naturalnego szacunku, jaki nowi wyborcy żywić mieli wobec klasy średniej. Niższe warstwy społeczne zdaniem Milla miały przy urnie wyborczej po prostu naśladować znajdujących się bezpośrednio ponad nimi w hierarchii społecznej reprezentantów middle rank. Jak bowiem informuje nas autor Eseju o rządzie, klasa średnia „[... powszechnie jest uznawana za najbardziej oświeconą i najbardziej cnotliwą część społeczności [...]. Nie może być żadnych wątpliwości co do tego, iż klasa średnia, która przydaje najwybitniejszych ornamentów nauce, sztuce i samemu prawodawstwu, wszystkiemu, co wznosi i udoskonala ludzką naturę, stanowi tę część społeczności, której opinia, gdyby granice reprezentacji zostały rozszerzone, ostatecznie by decydowała" (Mill, 2013b, s. 295, przeł. K.A.).

Nietrudno zinterpretować te słowa w duchu ideologicznej ekspresji klasowego interesu, tak też zresztą czynili niejednokrotnie interpretatorzy Milla. Można zapewne przynajmniej częściowo obronić autora Eseju o rządzie przed podobnymi zarzutami. Jak już wspomniałem, Mill, pomimo swoich niekonsekwencji i taktycznych ustępstw, uzależniał zasięg prawa do partycypacji politycznej od posiadania przez jednostki zdolności racjonalnego osądu własnego interesu. W tym kontekście przynależność do klasy średniej sama w sobie nie stanowi tytułu do uczestnictwa w polityce, podobnie jak nie stanowi go na przykład arystokratyczne pochodzenie. Natomiast posiadanie własności prywatnej i prokapitalistyczny etos klasy średniej mogą być interpretowane jako kryterium, choć z pewnością niedoskonałe, pozwalające zidentyfikować jednostki wyjątko- 
wo dobrze przygotowane do racjonalnej oceny rzeczywistości i podejmowania politycznych decyzji (Stimson, Milgate, 1993, s. 907-908).

Nie będę jednak w tym miejscu dalej rozwijał wątku uwikłania utylitarystycznej teorii polityki i demokracji w klasowe interesy. Chciałem natomiast podkreślić coś innego. Otóż w myśli Jamesa Milla relacja między klasą średnią a niższymi warstwami społecznymi zaczyna przypominać relację między reprezentantem a mandatariuszem w koncepcji mandatu wolnego (Krouse, 1982, s. 517-519). Reprezentant nie musi konsultować się z tymi, których reprezentuje, polega bowiem na własnym osądzie i kompetencjach. Nieco podobnie przedstawia się sytuacja z klasą średnią u Milla. Ma ona kształtować opinie tej części elektoratu, w stosunku do której zajmuje wyższe miejsce w hierarchii społecznej. Samodzielny osąd i działania w sferze politycznej ze strony mas ludowych są natomiast nie tylko niepotrzebne, ale mogą się nawet okazać niepożądane. Tym samym zresztą klasa średnia odgrywa u Milla rolę zbliżoną do elit politycznych w Schumpeterowskiej teorii demokracji.

Naszkicowany wyżej wątek roli klasy średniej w demokracji można próbować zbagatelizować jako pewną osobliwość teorii Jamesa Milla, nieobecną bądź przynajmniej niewyeksponowaną równie silnie $\mathrm{u}$ innych filozoficznych radykałów. Istnieją jednak również inne przesłanki wskazujące na silne tendencje elitarystyczne zawarte w ich wizji demokracji. Demokratyczne państwo w klasycznym utylitaryzmie ma się kierować zasadą użyteczności, a więc maksymalizować ogólne szczęście. Założenie to ma liczne konsekwencje. Jedną z nich jest konieczność utrzymywania aparatu państwa, który byłby racjonalnie zorganizowany i funkcjonowałby efektywnie. To zaś z kolei wymusza zarezerwowanie poczesnego miejsca w utylitarystycznej teorii demokracji dla specjalistycznych kompetencji, dla wiedzy niedostępnej laikom, dla decyzji podejmowanych przez organy niepodlegające bezpośredniej lub natychmiastowej politycznej odpowiedzialności. Tendencje oligarchiczne, elitarystyczne nieuchronnie towarzyszą więc dążeniu do zapewnienia maksymalnej sprawności biurokratycznej machinie państwa. Jeremy Bentham, twórca klasycznego utylitaryzmu, zdawał sobie $\mathrm{z}$ tego sprawę. Dostrzegał on, że władza zawsze sprawowana jest przez mniejszość nad większością oraz że w demokracji nie zniknie klasa rządząca (Harrison, 1993, s. 9899). Bentham rozpoczynał swoją publiczną działalność, poszukując oświeconego monarchy-protektora, który zechciałby zrealizować jego pomysły, w późniejszym okresie życia dokonał jednak konwersji na demokrację. Pozostał demokratą bardziej szczerym i konsekwentnym niż jego uczeń James Mill, starał się bowiem w swojej politycznej refleksji zaprojektować pewne zabezpieczenia przed nadmierną elitaryzacją demokracji. Jednocześnie jednak Benthamowi zależało na tym, aby demokracja miała kompetentnych zarządców i ekspertów u steru. W rezultacie rolą zwykłych obywateli było dla niego przede wszystkim periodyczne egzekwowanie kontroli wobec władzy, a nie bezpośrednie uczestnictwo w rządze- 
niu. Wymowna jest w tym kontekście analogia, jaką Bentham snuje między odpowiednim przygotowaniem do rządzenia a kunsztem rzemieślnika: „Nie każdy potrafi zrobić but, ale gdy już but zostanie wykonany, każdy jest w stanie stwierdzić, czy but ten go nie uwiera. Nie każdy może być szewcem, ale każdy może sobie wybrać swojego szewca" (Harrison, 1993, s. 97, przeł. K.A.).

Wpisanie demokracji w ramy utylitarystycznej teorii ma jeszcze jedną istotną konsekwencję. Skoro najwyższą zasadą moralną jest maksymalizowanie ogólnej użyteczności, oznacza to, że demokracja nie jest wartościowa sama w sobie, a jedynie jako środek do realizacji tego celu. Gdyby istniał oświecony despota bezinteresownie kierujący się dobrem poddanych oraz potrafiący lepiej od nich samych ocenić, co służy ich interesom, konsekwentny klasyczny utylitarysta musiałby przyznać, że taki despotyzm jest zgodny z zasadą użyteczności. Łatwo zbyć tę obiekcję wobec utylitaryzmu jako abstrakcyjną, wydumaną. O ile jednak klasyczni utylitaryści rzeczywiście wierzyli, że taki despota nie istnieje, o tyle też nieprzypadkowo drogi zasady użyteczności i demokracji rozchodzą się u Jamesa Milla w jego poglądach na kwestię kolonialną. Brytyjskie imperialne rządy w Indiach Mill postrzegał jako właściwy środek do osiągniecia celu, jakim jest maksymalizacja ogólnej pomyślności (Milgate, Stimson, 1993, s. 905-906), także tubylczej ludności. Argumentacja wiążąca uczestnictwo w polityce z posiadaniem odpowiedniej wiedzy, wykształcenia jest bronią obosieczną, może być zarówno narzędziem walki o demokratyzację, jak i (przynajmniej czasowego) ograniczenia władzy do kręgu tych, którzy wiedzą lepiej.

Wartość demokratycznego ustroju mierzona jest zatem rezultatami, jakie przynosi on dla ogólnej użyteczności. W myśl logiki klasycznego utylitaryzmu jednym z kluczowych kryteriów oceny demokracji będzie więc to, czy tworzy ona warunki dla rozwoju gospodarczego. Ten ostatni powinien bowiem pozwolić na zaspokojenie coraz większej liczby zróżnicowanych potrzeb i pragnień. James Mill opowiadał się stanowczo przeciw monarchii i arystokracji (a także przeciw ustrojowi mieszanemu usiłującemu połączyć je z elementami demokracji), ponieważ uważał, że te formy ustrojowe gwałcą zasadę użyteczności. Uprzywilejowują one w dostępie do bogactwa, które jest niezbędnym środkiem zaspokojenia pragnień, jednostkę bądź grupę kosztem reszty społeczeństwa. Demokracja nikogo w ten sposób nie faworyzuje i dzięki temu tworzy też zachętę dla każdego, aby poprzez własną pracę pomnażał swoje bogactwo. Jak powiada Mill: „Największe możliwe szczęście społeczeństwa jest [...] osiągane poprzez zapewnienie każdemu człowiekowi największej możliwej ilości wytworów jego pracy. [...] Stąd też okazuje się [it thus appears - przyp. K.A.], że to z uwagi na własność powstaje władza państwowa" (Mill, 2013b, s. 264, przeł. K.A.). W tym kontekście należy rozpatrywać również zalety i wady płynące z uczestnictwa obywateli w polityce. Z punktu widzenia klasycznych utylitarystów podlega ono tym 
samym zasadom co działalność ekonomiczna. Na przykład uczestnictwo w wyborach stanowi działanie instrumentalne, obciążone pewnymi kosztami, którego podejmowanie jest racjonalne pod warunkiem, że wartość jego spodziewanych efektów jest dla działającego podmiotu większa od owych kosztów. A zatem powyżej pewnego poziomu, niezbędnego do sprawnego funkcjonowania demokratycznego państwa, partycypacja polityczna stanowiłaby ubytek użyteczności. Wspomniałem już wcześniej o tym, że klasyczni utylitaryści byli zwolennikami demokracji pośredniej. Obecnie można lepiej zrozumieć, dlaczego właśnie ta forma ustroju demokratycznego najlepiej odpowiadała ich oczekiwaniom. Przeciw demokracji bezpośredniej podnosili oni co prawda znajome zarzuty, iż nie jest ona możliwa do praktykowania na szerszą skalę w dużych i złożonych społeczeństwach nowoczesnego świata. W naszych czasach organizacyjne i techniczne bariery dla częstszego stosowania demokracji bezpośredniej zostały postawione pod znakiem zapytania przez rozwój nowych technologii komunikacyjnych. Wątpliwe jednak, czy zmieniłoby to zasadniczo stosunek klasycznych utylitarystów do demokratycznej partycypacji politycznej. Z ich perspektywy stanowi ona koszt, którego nie warto ponosić powyżej pewnego poziomu. Nie warto, ponieważ wiązałoby się to $\mathrm{z}$ utratą czasu i energii, które mogłyby zostać spożytkowane na bezpośrednie pomnażanie dobrobytu. W klasycznym utylitaryzmie nie ma miejsca na Arystotelesowsko-Arendtowską afirmację polityki jako dziedziny, w której człowiek najpełniej realizuje swoją istotę. Jeśli niektórzy nadają polityce taką rangę, to jest to co najwyżej ich indywidualna preferencja, niewskazana jednak w przypadku większości obywateli. Klasyczni utylitaryści, w szczególności zaś James Mill, prezentują zatem „ekonomiczną teorię demokracji”, w której polityka odgrywa rolę służki ekonomii (Krouse, 1982, s. 516).

Dochodzimy w tym miejscu do ciekawej zbieżności między klasycznym utylitaryzmem a teorią Schumpetera. On także opowiada się za demokracją pośrednią jako jedyną możliwą w większych, nowoczesnych społeczeństwach. Co więcej, związek między ekonomią a demokracją $\mathrm{w}$ jeszcze większym stopniu przenika analizy austriackiego uczonego. O ile utylitarystyczna teoria demokracji eksponuje analogie między aktywnością polityczną i ekonomiczną (a nawet posuwa się do podporządkowania pierwszej z nich tej drugiej), o tyle Schumpeter otwarcie czyni z modelu rynku narzędzie analizy demokratycznej polityki. Twierdzi on, że relacje między głównymi politycznymi aktorami, czyli partiami i przywódcami politycznymi a wyborcami, dosyć wiernie odwzorowują stosunki między producentami dóbr a ich konsumentami (Held, 2006, s. 149-150). Polityk demokratyczny to przedsiębiorca (entrepreneur), który od innych biznesmenów różni się tylko tym, że interesuje go eksploatacja głosów wyborców, a nie na przykład złóż ropy naftowej (Schumpeter, 2009, s. 356). Przypomnijmy, że Schumpeter w swojej definicji demokracji kładzie nacisk na „walkę konkurencyjną o głosy wybor- 
ców" (Schumpeter, 2009, s. 337). W ekonomii konkurencja doskonała występuje niezmiernie rzadko, w polityce jego zdaniem nie występuje w ogóle (Schumpeter, 2009, s. 339). Demokracja natomiast charakteryzuje się tym, iż mamy do czynienia z rywalizacją mniej lub bardziej licznej grupy podmiotów, które stosując mniej lub bardziej uczciwe metody, starają się osiągnąć zwycięstwo wyborcze. Pewną osobliwością tego demokratycznego rynku jest wszakże niemal zupełny brak podmiotowości konsumentów, czyli wyborców. W przypadku oligopolicznej konkurencji zakres wyboru konsumenta jest mocno ograniczony, a porozumienie między głównymi producentami pozwala im narzucić korzystne dla siebie ceny. Ostatecznie jednak konsument może przynajmniej samodzielnie zdecydować, od którego producenta kupi dany produkt. Tymczasem w Schumpeterowskiej teorii demokracji nie jest nawet zupełnie jasne, czy obywatel, głosując na konkretną partię, wyraża w ten sposób swoją autonomiczną wolę. Skoro bowiem w przypadku innych działań politycznych jego wola jest bądź nieczynna, bądź mówiąc Schumpeterowskim idiomem - „sfabrykowana” przez zewnętrzne wpływy, dlaczego akt głosowania miałby stanowić wyjątek? Trzymając się rynkowej analogii, jest tak, jak gdyby producenci byli w stanie za pomocą reklamy, marketingu i PR-u zdobyć niemalże zupełną kontrolę nad konsumentami.

\section{Zakończenie}

Celem niniejszego artykułu nie było oczywiście stawianie znaku równości między poglądami klasycznych utylitarystów na demokrację a teorią Schumpetera. Zdaję sobie sprawę z tego, że istnieją pomiędzy nimi autentyczne i głębokie różnice. Moja teza jest znacznie skromniejsza: Schumpeter, świadomie lub nie, przecenia dystans dzielący jego teorię demokracji od tej przedstawionej przez klasyczny utylitaryzm. Trudno mu mieć to za złe, zważywszy na to, jak często inni autorzy także starają się przedstawić swoje własne stanowisko jako w pełni oryginalne, bagatelizując tym samym podobieństwa w stosunku do poprzedników, a nawet bezpośrednie intelektualne długi. W tym przypadku doniosłość nieadekwatnej autoprezentacji może jednakże daleko wykraczać poza ramy indywidualnego przypadku.

Kiedy klasyczni utylitaryści głosili swoją teorię demokracji, miała ona jednoznacznie normatywny charakter. Demokracja w częstym obecnie rozumieniu powszechnego prawa wyborczego i politycznej kontroli nad władzą wykonywanej przez obywateli nie istniała wówczas jeszcze w żadnym państwie na świecie. Gdy po upływie ponad stu lat Schumpeter opublikował pracę Kapitalizm, socjalizm, demokracja, rościł sobie pretensje do większego realizmu. Jego teoria demokracji miała opisywać rzeczywiste, praktyczne funkcjonowanie istniejących demokracji, w których elity polityczne sprawują władzę i rywalizują o głosy 
wyborców. Schumpeterowska teoria demokracji nie jest jednak neutralnym opisem politycznej rzeczywistości, o ile takowy w ogóle może istnieć, zawiera w sobie wyraźny komponent normatywny. Schumpeter nie mówi: „tak jest, tak demokracja działa”, a raczej: „tak musi być, tak demokracja musi działać”. Obecnie zaś, po upływie kolejnych kilkudziesięciu lat, Schumpeterowski obraz demokracji wydawać się może bardziej prawdziwy niż w momencie, w którym powstał.

Chciałbym zasugerować, że naszkicowana wyżej sekwencja momentów historycznych układa się w pewną całość. Klasyczny utylitaryzm towarzyszył narodzinom nowoczesnych, kapitalistycznych społeczeństw, siłą rzeczy był więc buntowniczym głosem krytyki wobec odchodzącego w przeszłość porządku społecznego. Jednym z dążeń architektów nowego porządku była zaś emancypacja ekonomii od polityki, likwidacja pozostałości feudalnych przywilejów i monopoli etc. Schumpeter zdawał sobie sprawę z tego rozdzielenia polityki od ekonomii, uznania tej ostatniej za część sfery prywatnej, i trafnie interpretował demokrację liberalną jako jego polityczny rezultat. Wieszczył on co prawda także upadek kapitalizmu i zwycięstwo socjalizmu, ale jego zdaniem socjalistyczny eksperyment bynajmniej nie miał oznaczać demokratyzacji zarządzania przedsiębiorstwami (Held, 2006, s. 151-152). Starałem się zresztą pokazać, w jaki sposób w poglądach Schumpetera odzwierciedlenie znajduje rosnąca dominacja ekonomii nad polityką. Obecnie proces ten posunął się jeszcze dalej, zjawisko postępującej ekonomizacji, „marketyzacji” obejmuje już nie tylko politykę, ale także inne dziedziny. Utylitaryzm stał się zaś nie tyle stanowiskiem dominującym wśród filozofów moralności, ile bardzo znaczącym nurtem moralności publicznej współczesnych społeczeństw demokratycznych, w których wszystko daje się ująć w postaci cost-benefit analysis. Wydaje się, że w dobie tego, co interpretowane jest, choć mam wątpliwości czy słusznie, jako populistyczna rebelia przeciw demokracji liberalnej, Schumpeterowski z ducha „realizm demokratyczny” nieco przygasł. Nie oznacza to jednak, że utracił on zwolenników nie tylko (i nie przede wszystkim) w kręgu naukowców, ale wśród elit politycznych, finansowych, medialnych. Pytanie, do jakiego prowokuje refleksja Schumpetera, a które należałoby postawić jego współczesnym następcom, brzmi: czy rzeczywiście opowiadają się oni za "realizmem demokratycznym”, czy też dwa człony tego określenia należałoby rozdzielić?

\section{Literatura}

Bentham, J. (1958). Wprowadzenie do zasad moralności i prawodawstwa, przeł. B. Nawroczyński. Warszawa: PWN.

Dahl, R. (1961). Who Governs? Democracy and Power in an American City. New Haven: Yale University Press. 
Halévy, É. (1960). The Growth of Philosophic Radicalism. Boston: Beacon Press.

Hamburger, J. (1962). „James Mill on Universal Suffrage and the Middle Class”. The Journal of Politics, 24, 1, s. 167-190.

Harrison, R. (1993). Democracy. London-New York: Routledge.

Ingham, S. (2016). „Popular Rule in Schumpeter's Democracy”. Political Studies, 64, 4, s. $1071-1087$.

Krouse, R.W. (1982). „Two Concepts of Democratic Representation: James and John Stuart Mill”. The Journal of Politics, 44, 2, s. 509-537.

Medearis, J. (2001). Joseph Schumpeter's Two Theories of Democracy. Cambridge, MALondon: Harvard University Press.

Mill, J. (2001). „Esej o rządzie”. W: S. Filipowicz, A. Mielczarek, K. Pieliński, M. Tański (red.). Historia idei politycznych: wybór tekstów, t. 2. Warszawa: Wydawnictwa Uniwersytetu Warszawskiego.

Mill, J. (2013a). „Education”. W: D.M. Hart (ed.). The Political Writings of James Mill: Essays and Reviews on Politics and Society, 1815-1836. Liberty Fund.

Mill, J. (2013b). „Government”. W: D.M. Hart (ed.). The Political Writings of James Mill: Essays and Reviews on Politics and Society, 1815-1836. Liberty Fund.

Przeworski, A. (1999). „Minimalist Conception of Democracy: A Defense”. W: I. Shapiro, C. Hacker-Cordón (eds.). Democracy's Value. Cambridge: Cambridge University Press. Sartori, G. (1998). Teoria demokracji, przeł. P. Amsterdamski, D. Grinberg. Warszawa: Wydawnictwo Naukowe PWN.

Schumpeter, J. (2009). Kapitalizm, socjalizm, demokracja, przeł. M. Rusiński, wstęp S. Mikosik. Warszawa: Wydawnictwo Naukowe PWN.

Stimson, S.C., Milgate, M. (1993). „Utility, Property, and Political Participation: James Mill on Democratic Reform". The American Political Science Review, 87, 4, s. 901-911.

\section{Streszczenie}

Przedstawiona przez Josepha Schumpetera teoria demokracji jako metody selekcji elit politycznych pozostaje jednym $\mathrm{z}$ istotniejszych i jednocześnie najbardziej kontrowersyjnych punktów odniesienia we współczesnych dyskusjach poświęconych demokracji. Niniejszy artykuł dowodzi jednak, że Schumpeter buduje fałszywe przeciwstawienie między własną teorią a klasyczną teorią demokracji, za której eksponentów uznaje utylitarystów takich jak Jeremy Bentham i James Mill. Po pierwsze, większość zarzutów Schumpetera pod adresem utylitarystycznego ujęcia demokracji jest chybiona. Po drugie, istnieją pewne podobieństwa i linie ciągłości pomiędzy teorią demokracji głoszoną przez klasyczny utylitaryzm a teorią samego Schumpetera. W klasycznym utylitaryzmie obecny był na przykład wyraźny komponent elitarystyczny, który u Schumpetera uległ jeszcze wzmocnieniu na skutek uczynienia przezeń z (oligopolicznej) rynkowej konkurencji wzorca demokratycznej polityki.

Słowa kluczowe: demokracja, elitaryzm, Joseph A. Schumpeter, utylitaryzm 